\title{
IMPLEMENTASI NILAI-NILAI EKONOMI SYARIAH DI PASAR BELAWA KECAMATAN MALANGKE KABUPATEN LUWU UTARA
}

\section{Prof. Hamzah Kamma,M.HI}

Fakultas Syariah Institut Agama Islam Negeri (IAIN) Palopo

Fasiha,M.EI

Fakultas Ekonomi dan Bisnis Islam Institut Agama Islam Negeri (IAIN) Palopo

\section{Sarwia}

Fakultas Ekonomi dan Bisnis Islam Institut Agama Islam Negeri (IAIN) Palopo

\begin{abstract}
The purpose of this study was to determine the application of Islamic economic values in the Belawa Market, Malangke sub-district, North Luwu Regency. In this study the authors used a type of qualitative descriptive research. Data sources used are primary data sources and secondary data. Primary data obtained from interviews with traders in the Belawa Market, while secondary data sources were obtained from library studies and documents. There are also data collection techniques used through observation, interviews, and documentation. The results of the study show that sharia economic forms in the Belawa Market are those which traders are not responsible for their merchandise and do not apply fairly to their consumers so that consumers feel disadvantaged and wronged by the treatment of traders and consumers who are not comfortable in conducting transactions conducted by traders irresponsible and unfair traders. The application of Islamic economic values in the Belawa Market is not well organized due to a lack of traders' knowledge of Islamic economic values and there are still some traders who cheat in conducting transaction activities and do not pay attention to ethics in trading in accordance with Islamic law.
\end{abstract}

Keywords : Islamic Economic Law, Belawa Market

\begin{abstract}
Abstrak
Tujuan penelitian ini untuk mengetahui penerapan nilai-nilai ekonomi syariah di Pasar Belawa kecamatan Malangke Kabupaten Luwu Utara. Dalam penelitian ini penulis menggunakan jenis penelitian deskriptif kualitatif. Sumber data yang digunakan adalah sumber data primer dan data sekunder. Data primer diperoleh dari hasil wawancara dengan pedagang yang ada di Pasar Belawa, sedangkan sumber data sekunder di peroleh dari studi pustaka dan dokumen. Ada pun teknik pengumpulan data yang digunakan melalui observasi, wawancara, dan dokumentasi. Hasil penelitian menunjukkan bahwa Bentuk-bentuk ekonomi syariah di Pasar Belawa yaitu masih ada yang pedagang tidak bertanggung jawab atas barang dagangannya dan tidak berlaku adil terhadap konsumennya sehingga konsumen merasa dirugikan dan terzalimi oleh perlakuan pedagang dan konsumen tidak merasa nyaman dalam melakukan transaksi yang dilakukan oleh pedagang yang tidak bertanggung jawab dan pedagang yang tidak
\end{abstract}


adil. Penerapan nilai-nilai ekonomi syariah di Pasar Belawa yaitu belum tertata dengan baik disebabkan karena kurangnya pengetahuan pedagang tentang nilai-nilai ekonomi syariah dan masih ada sebagian pedagang yang berlaku curang dalam melakukan kegiatan transaksi dan tidak memperhatikan etika dalam berdagang sesuai dengan syariat Islam.

\section{Kata Kunci : Nilai-Nilai Ekonomi Syariah, Pasar Belawa}

\section{PENDAHULUAN}

Dalam kehidupan sehari-hari banyak yang diperlukan oleh anggota masyarakat. Mulai dari keperluan pokok sehari-hari sampai kepada keperluan lainnya. Tidak semua orang memiliki apa yang diperlukannya. Barang-barang yang diperlukannya itu ada yang dijual di pasar dengan demikian, terjadilah jual beli yang diperbenarkan diperjual menurut Islam adalah barang-barang yang tidak diharamkan, seperi babi, miniman keras, dan lain-lain yang diharamkan agama Islam. Manusia merupakan makhluk sosial, yang artinya manusia tidak bisa hidup sendiri dalam memenuhi kebutuhan untuk mempertahankan hidupnya. Sudah seharusnya manusia saling tolong menolong ${ }^{1}$

Ada tiga pelaku yang memainkan peranan penting hingga terjadinya suatu transaksi bisnis. Ketiganya pelaku tersebut terdiri dari penjual, pembeli, dan perantara. Artinya proses terlaksananya transaksi bisnis baru dapat dijalankan oleh dua pelaku misalnya dilakukan hanya oleh penjual dan pembeli. ${ }^{2}$ Pasar adalah tempat bertemunya antara penjual dan pembeli, atau lebih jelasnya daerah, tempat, area yang mengandung kekuatan permintaan dan penawaran yang saling bertemu dan membentuk harga. ${ }^{3}$

Pelaku pasar pada dasarnya terdiri atas rumah tangga dan perusahaan- perusahaan sementara pasar dapat diklasifikasikan menjadi pasar input dan pasar output. Rumah tangga dapat terdiri atas perseorangan atau kelompok (misalnya keluarga), sedangkan perusahaan dapat berupa perseorangan atau lembaga usaha di pasar input, rumah tangga bertindak sebagai penyedia faktor produksi, yang dibutuhkan oleh perusahaan,

\footnotetext{
${ }^{1}$ M. Ali Hasan, Zakat Dan Infak Satu Solusi Mengatasi Problema Sosial Di Indonesia, (cet.II; Jakarta: Kencana,2008), hal.46.

${ }^{2}$ Kasmir, Pengantar Manajemen, (Cet. I; Jakarta: Kencana Prenada Media, 2010), hal 50.

${ }^{3}$ M. fuad,eat.al, pengantar bisnis, (Cet. I; Jakarta: Gramedia Pustaka Utama, 2000), hal. 120.
} 
sedangkan di pasar output rumah tangga adalah konsumen bagi barang dan jasa yang dihasilkan oleh perusahaan. Individu memiliki kebebasan untuk bertransaksi di pasar input maupun di pasar output bertindak sebagai produsen maupun sebagai konsumen, dan dilakukan sendiri atau kelompok.

Ajaran Islam sangat menghargai pasar sebagai wahana bertransaksi atau perniagaan yang halal (sah/ legal) dan thayyib (baik) sehingga secara umum merupakan mekanisme alokasi dan distribusi sumber daya ekonomi yang paling ideal. Penghargaan pasar terhadap mekanisme pasar berangkat dari ketentuan Allah sebagai perniagaan harus dilakukan dengan cara yang baik berdasarkan prinsip saling ridha ('an taradin minkum) sehingga tercipta keadilan. Pasar merupakan mekanisme perniagaan yang memenuhi kriteria tersebut. Mekanisme pasar merupakan suatu kegiatan yang bersifat massal (impersonal) dan alamiah (natural) sehingga mencerminkan kondisi ekonomi masyarakat lebih luas. Situasi bersaing sempurna (perfect compotition market), tidak ada pelaku pun yang secara individual dapat mengendalikan mekanisme pasar.

Islam menolak konsep pasar dalam bentuk persaingan bebas tanpa batas sehingga mengabaikan norma dan etika. Pasar yang seperti ini tidak mampu merelisasikan tujuan mencapai falah, bahkan mungkin akan mendistorsirnya. Dalam pasar yang Islami, para pelaku pasar didorong oleh semangat bersaing untuk meraih kebaikan (fastabiqul khairat) sekaligus kerja sama dan tolong- menolong (ta'awun) dalam bingkai nilai dan moralitas Islam.

Para pelaku pasar tidak hanya mengejar keuntungan materil, tetapi juga barakah Allah. Pasar akan menjadi arena perniagaan komoditas yang halalan toyyiban saja sehingga yang haram harus ditinggalkan. Transaksi yang mengandung riba, perjudian, alkohol, daging babi, dan komoditas lainnya tidak akan terdapat dalam pasar. Aktivitas pasar juga harus mencerminkan persaingan yang sehat (fair play), kejujuran (honesty), keterbukaan (transparancy), dan keadilan (justice), sehingga harga yang tercipta 
adalah harga yang adil (just price). Dengan kata lain, pasar ini tidak mengandung deviasi dari nilai dan moralitas Islam. ${ }^{4}$

Pelaku pasar mempunyai tujuan utama dalam melakukan sebuah transaksi, yaitu mencapai ridha Allah demi mewujudkan kemaslahatan hidup bersama di samping kesejahteraan individu. Selain itu, pasar merupakan wahana untuk mengapresiasikan kepemilikan individu.

Dalam pasar penjual dan pembeli dapat merealisasikan segala keinginanya dalam melakukan transaksi atas barang dan jasa. Selain itu, ada faktor lain yang mendorong terbentuknya pasar. Meraih keuntungan (profit) merupakan faktor dominan bagi terbentuknya mekanisme pasar, seperti halnya investasi yang dilakukan oleh pelaku ekonomi dalam mewujudkan kesejahteraan hidup manusia.

Konsep mekanisme pasar yang ditawarkan oleh kapitalisme, dalam perkembangannya telah menimbulkan monopoli pasar dimana para pengusaha atau pemilik modal mengendalikan harga sesuai kebutuhan mereka. Dengan demikian, harga yang terbentuk dalam pasar bukanlah hasil supply dan demand yang ada, melainkan ketentuan dari pada pemilik modal. Hal inilah yang kemudian berdampak pada minimnya perfect competition yang pada akhirnya persaingan pasar pun menjadi tidak sehat. $^{5}$

Konsep pasar dalam Islam sesuai dengan Alquran ini sangat jelas bahwa berdagang dalam Islam harus mempunyai beberapa yang harus diketahui dalam berdagang seperti halnya dengan ridha adalah segala transaksi yang dilakukan haruslah atas dasar kerelaan masing-masing pihak dari pembeli maupun dari pihak penjual agar tidak ada pihak yang dirugikan baik dari pedagang maupun konsumen. Karena kepuasaan kenyamanan konsumen adalah salah satu tujuan dari berdagang yang baik sehingga didalam perdagangan pasar yang sehat akan menghasilkan keuntungan yang diridai Allah karena apabila didalam suatu pasar pedagang yang menimbun serta tidak

\footnotetext{
${ }^{4}$ P3EI, ekonomi Islami, (Jakarta; Rajawali Pers, 2009), hal. 81-83.

${ }^{5}$ Zikrul Hakim, ekonomi Islam, ( Cet. III; Jakarta: edisi revisi, 2007), hal. 86-87.
} 
memberitahukan kepada konsumen bahwa barang yang dibelinya itu rusak atau cacat serta tidak mengetahui berdagang dalam Islam itu seperti apa, maka pedagang yang menimbun barang dagangannya akan hanya memikirkan keuntungan sebanyakbanyaknya tapi berdampak menghambat perkembangan pasar serta membahayakan banyak orang. ${ }^{6}$

Mengenai implementasi nilai-nilai ekonomi syariah di pasar menurut ekonomi Islam para pedagang di pasar masih banyak yang melakukan persaingan yang tidak sehat terutama dalam mencari keuntungan dimana para pedagang yang ada di pasar tidak memahami tentang apa yang dilakukannya itu tidak sesesuai dengan syariat Islam yang mereka tau hanya untuk mencari keuntungan saja tanpa memikirkan kerugian yang dialami oleh konsumen dan mungkin konsumen merasa dirugikan dan juga merasa suatu ketidak adilan dan di dzalimi terkait dengan harga yang terjadi di pasar maka disinilah implementasi nilai-nilai ekonomi Islam yang bisa mengatasi pertentangan ekonomi yang terjadi di pasar.

Ada beberapa faktor yang dapat menghambat implementasi nilai-nilai ekonomi syariah di pasar yaitu : faktor pendidikan dan faktor usia. Dimana pendidikan para pedagang yang ada di pasar masih minim dan kurang mengetahui nilai-nilai ekonomi dalam Islam sehingga mereka hanya berdagang tanpa mengetahui hal yang dilakukan tersebut tidak sesuai syariat Islam. Sedangkan, faktor usia di mana usia pedagang yang ada di pasar pada umunya sudah lanjut usia sehingga ia tidak mengetahui aturanaturan dan etika dalam berdagang dan para pedagang tersebut hanya ingin mencari keuntungan (laba) yang banyak.

Pelaksanaan perdagangan pada saat ini di pasar tidak sesuai dengan syariat Islam serta nilai-nilai ekonomi syariah terabaikan dan para pedagang melakukan perdagangan yang tidak sehat dan tidak sesuai etika yang berlaku dalam ekonomi syariah dari situlah saya ingin meneliti para pedagang yang ada di pasar untuk mengetahui cara berdagang yang Islami atau hanya sekedar berdagang saja dan hanya

\footnotetext{
${ }^{6}$ Raodah, op. cit., hal. 38.
} 
untuk mencari keuntungan tanpa memperhatikan aturan-aturan berdagang dalam Islam seperti apa. Apa bila para pedagang secara terus menerus melakukan perdagangan yang curang maka perekonomian saat ini secara berlahan akan hancur kerena terdapat banyak yang melakukan perdagangan yang kurang sehat dan akan merugikan para konsumen maka, dari itu implementasi nilai-nilai ekonomi syariah yang dapat mengatur jalannya perdagangan di pasar dimana yang didalamnya mempunyai aturan, prinsip-prinsip dalam berdagang dan dapat memberikan semangat baru dalam membangun perekonomian yang lebih baik dan kebebasan dalam berdagang tidak disalah gunakan oleh para pedagang serta memperhatikan etika dalam berdagang. Dalam tulisan ini akan dibahas tentang bentuk bentuk penerapan nilai-nilai Ekonomi Syariah di Pasar Belawa Kecamatan Malangke Kabupaten Luwu Utara.

\section{METODE PENELITIAN}

Penelitian ini menggunakan jenis penelitian kualitatif, yaitu penelitian yang berusaha menuturkan pemecahan masalah yang ada. Adapun lokasi penelitian dilaksanakan di Pasar Belawa Kecamatan Malangke Kabupaten Luwu Utara sebagai pertimbangan bahwa implementasi nilai-nilai ekonomi Islam di pasar tersebut tidak sesuai dengan syariat Islam, sehingga diperlukan upaya penelitian agar dapat diketahui sejauh mana pemahaman masyarakat terhadap implementasi nilai-nilai ekonomi syariah di pasar tersebut. Adapun informan penelitian yaitu para pedagang yang ada di Pasar Belawa. Pengumpulan Data dilakukan dengan menggunakan metode Library Research dan Field Research. Kemudian teknik pengolahan data yang digunakan yaitu Editing dan Codeting. Setelah data dan keterangan yang diperlukan dianggap sudah cukup, selanjutnya diolah dengan menggunakan analisis data deskriptif kualitatif kemudian mengambil kesimpulan dengan cara menggunakan metode deduktif, metode induktif. Metode komperatif. 


\section{PEMBAHASAN}

\section{Profil Lokasi Penelitian}

Pasar Belawa Baru juga mempunyai ciri khas dengan pasar umum lainnya yang ada di daerah malangke, selain setiap hari terdapat keramaian ada juga hari-hari tertentu dimana bagi pembeli dan penjual saling bertatap muka melakukan transaksi yaitu pada hari Rabu dan hari Minggu. Keberadaan Pasar Belawa Baru banyak dirasakan manfaatnya oleh masyarakat dan letak pasar dipertengahan penduduk sehingga tidak hanya penduduk Belawa Baru saja yang melakukan transaksi di pasar tersebut. Akan tetapi, juga masyarakat yang ada di luar wilayah belawa baru seperti, sebelah Timur ada Laba Lubu, Kambisa, Pettalandung, dan sekitarnya. Sebelah Barat ada Lettekan, Massangan, dan sekitarnya. Sebelah Utara ada daerah Giri Kusuma dan Tolada.

\section{Penerapan Nilai-Nilai Ekonomi Syariah di Pasar Belawa Kecamatan Malangke Kabupaten Luwu Utara}

Ekonomi Islam atau Ekonomi Syariah mempunyai tujuan untuk memberikan keselarasan bagi kehidupan di dunia dan akhirat. Nilai Islam bukan semata-semata hanya untuk kehidupan muslim saja, tetapi seluruh makhluk hidup di muka bumi. Dimana dalam proses Ekonomi Islam dalam pemenuhan kebutuhan manusia yang berlandaskan nilai-nilai Islam guna untuk mencapai pada tujuan agama. Dalam segenap aspek kehidupan bisnis dan transaksi, dunia Islam mempunyai sistem perekonomian yang berbasiskan nilai-nilai dan prinsip-prinsip syariah yang bersumber dari Al quran dan Hadits serta dilengkapi dengan Al Ijma dan Al qiyas. Ekonomi Islam mengedepankan nilai kebebasan dalam bertindak dan berbuat dengan dilandasi oleh ajaran agama serta nilai keadilan dalam kepemilikan. Dalam pandangan Islam adalah sesuatu yang sudah menjadi ketentuan bahwa setiap manusia memiliki kemampuan dan kecakapan yang berbeda-beda. Namun demikian perbedaan tersebut tidaklah dibenarkan menjadi sebuah alat untuk mengekspliotasi orang yang lain. Sistem ekonomi Islam, melarang individu mengumpulkan harta secara berlebihan. Sebab, dengan adanya pengumpulan harta secara berlebihan akan berakibat pada 
perekonomian dimasa yang akan datang. Oleh karena itu, penimbunan merupakan prilaku yang dilarang dalam ajaran Islam.

Dalam melakukan suatu aktivitas kita dianjurkan mencari ridho Allah bukan semata-mata mencari keuntungan materi saja kita juga harus memperhatikan hal-hal yang tidak sesuai dengan aturan agam kita. Kegiatan dilakukan hanya semata-mata untuk beribadah dan mengabdi kepada Allah. Hal ini didasarkan semua amal dan perbuatan manusia dimana akan dipertanggung jawabkan di akhirat kelak. Selain itu melakukan aktivitas perekonomian diniatkan ibadah agar mendapatkan hasil lebih daripada niat untuk mencari harta. Dengan niat yang baik maka kita akan mendapat keuntungan yaitu, harta dan pahala yang diridhoi oleh Allah Swt.

Tidak bisa dipungkiri bahwa aktivitas ekonomi dilakukan karena ingin mendapatkan sebuah kemakmuran hidup di dunia, bisa memenuhi kebutuhan hidup dan lain sebagainya. Namun dalam ekonomi syariah, kehidupan akhirat tidak boleh dilupakan, karena kehidupan kebutuhan hidup, namun hal itu tidak boleh membuat kita lupa akan akhirat justru harus menambah kepekaan dan ketaatan kita akan Allah.

Kegiatan ekonomi menurut pandangan Islam adalah suatu aktivitas yang mampu memberikan dampak baik kepada semua orang atau masyarakat. Di harapkan dengan adanya ekonomi ini, kemakmuran dan kesejahteraan masyarakat dapat dicapai dan dirasakan manfaatnya. Ekonomi syariah menjunjung nilai sosial, dimana tidak ada perbedaan status semua orang berhak mendapatkan dan merasakan sebuah kemakmuran dan bebeas untuk berkreasi. Pada dasarnya prinsip ekonomi syariah adalah mementingkan kemaslahatan umat bukan mudharat.

Dengan mengacu kepada aturan Ilahiah, maka setiap perbuatan manusia mempunyai nilai moral dan ibadah. Pada paham naturalis, sumber daya menjadi faktor terpenting dan pada pada paham monetaris menempatkan modal financial sebagai yang terpenting. Dalam ekomoni Islam sumber daya insanilah yang terpenting. Ekonomi Islam bersumber pada Islam itu sendiri yang meliputi tiga asas pokok. Ketiganya secara asasi dan bersama mengatur teori ekonomi dalam Islam, yaitu asas akidah, akhlak, dan asas hukum (muamalah). 
Nilai-nilai syariah adalah suatu bentuk yang harus diterapkan di Pasar Belawa dalam kehidupan sehari-hari agar di dalam perdagangan masyarakat tidak semenamena dalam melakukan kecurungan dalam berdagang. Agama Islam memang menghalalkan usaha perdagangan, perniagaan dan atau jual beli. Namun tentu saja untuk orang yang menjalankan usaha perdagangan secara Islam, dituntut menggunakan tata cara khusus, ada aturan mainnya yang mengatur bagaimana seharusnya seorang Muslim berusaha di bidang perdagangan agar mendapatkan berkah dan ridha Allah SWT di dunia dan akhirat. ${ }^{7}$

\section{Kejujuran dalam penyampaikan barang yang rusak yang telah di beli oleh pelanggan}

Penulis telah melakukan wawancara kepada Ibu HJ. Atirah ia mengatakan bahwa ia tidak jujur dalam berdagang dan tidak memberi tahu kepada pelanggan bahwa barang yang di beli rusak, apa bila memberitahukan kepada pelanggan maka keuntungan yang di dapat berkurang karena barang tersebut tidak laku terjual. ${ }^{8}$

Dilihat dari pernyataan diatas bahwa pedagang yang ada di Pasar Belawa hanya memikirkan keuntungan yang tinggi saja tanpa memikirkan kerugian yang dialami oleh pelanggan. Dimana kejujuran dalam berdagang sangat penting bagi para pedagang untuk mendapatkan kepercayaan bagi pelanggan agar pelanggan tersebut merasa puas.

Seorang pedagang wajib berlaku jujur dalam melakukan usaha jual beli. Jujur dalam arti luas tidak berbohong, tidak menipu, tidak mengada-ngada fakta, tidak berkhianat, serta tidak pernah ingkar janji dan lain sebagainya. Karena berbagai tindakan tidak jujur selain merupakan perbuatan berdosa juga sangat berpengaruh negatif kepada kehidupan pribadi dan keluarga pedagang itu sendiri dan juga akan mempengaruhi kehidupan bermasyarakat.

${ }^{7}$ Ladlul Muksinin, Perdagangan dalam Islam,http://pustaka mediasyariah. Blogspot. co. $\underline{\mathrm{id} / 2015 / 05 / \mathrm{html} \text { (23 Januari 2017) }}$

${ }^{8} \mathrm{Hj}$. Atira, Wawancara, Malangke, Tanggal 15 Januari 2017. 
Penulis telah melakukan wawancara kepada bapak Kasman ia mrngatakan jika ada barang dagannya yang rusak ia memberitahukan kepada pelanggan karena dengan memberitahukan kepada pelanggan kita dapat diberikan kepercayaan kepada pelaggan tersebut dan orang merasa bangga kepada kita. ${ }^{9}$

Ada pun tindakan yang berhubungan nilai-nilai ekonomi syariah adalah tidak meninggalkan sholat, mempunyai niat yang lurus, tidak melalaikan diri dari ibadah, tidak mudah putus asa, selalu bertawakal kepada Allah Swt., dan yang paling utama adalah selalu bersyukur terhadap apa yang diperoleh setiap harinya.

Dalam ajaran Islam, kejujuran merupakan syarat yang paling mendasar dalam kegiatan bisnis. Rasulullah sangat menganjurkan kejujuran dalam segala bentuk dan akan membawa kepada kebajikan-kebajikan dan akan membawa pada surga. Demikian pula sebaliknya kebohongan akan membawa pelakunya pada keburukan dan akhiratnya ke neraka. Rasulullah melarang segala bentuk aktivitas bisnis yang dilakukan dengan penipuan karena penipuan dapat merugikan orang lain dan melaggar hak asasi dalam bisnis yang suka sama suka.

Penulis telah melakukan wawancara dengan bapak Firman ia mengatakan ada sebagian pedagang yang berlaku curang sebab ketika ada barang yang rusak pedagang tersebut tidak memberitahukannya pada hal pedagang tau bahea barang tersebut rusak itulah yang membuatnya tidak merasa nyaman terhadap pedanag tersebut. ${ }^{10}$

Seorang pebisnis harus berlaku jujur yang dilandasi keinginan agar orang lain mendapatkan kebaikan dan kebahagian sebagaimana yang ia inginkannya dengan cara menjelaskan kelemahan, kekurangan, serta kelebihan barang yang ia ketahui kepada orang atau konsumennya, baik yang terlihat maupun yang tidak terlihat oleh orang lain. Masyarakat umum sering tertipu perlakuan para pebisnis seperti ini. ${ }^{11}$

\footnotetext{
${ }^{9}$ Kasman, Wawancara, Pedagang, Malangke, Tanggal 25 Februari 2017.

${ }^{10}$ Firman, Wawancara, Pembeli, Malangke, Tanggal, 25 Februari 2017

${ }^{11}$ Idri, Hadis Ekonomi Dalam Perspektif Hadis Nabi (Cet.I; Jakarta: Prenadamedis Grop, 2015), hal. 356
} 
Kejujuran sangatlah penting dalam perdagangan, konsumen atau pelaggan tidak dirugikan dan penjual juga mendapatkan keuntungan secara sah atau halal. Prinsipnya adalah sama-sama diuntungkan. Konsumen mendapatkan apa yag mereka butuhkan sesuai dengan haknya. Penjual juga mendapatkan keuntungan yang sesuai dan berkah. $^{12}$

\section{Pedagang meminta pedagang lainnya untuk memuji barang dagangannya agar laku}

Hasil wawancara dengan bapak Rudi, ia mengatakan bahwa dia tidak pernah menyuruh orang lain memuji barangnya biarkanlah mereka sendiri yang menilai barang yang ia akan beli. ${ }^{13}$

Melihat dari kondisi diatas memuji barang secara berlebihan itu dilarang dalam Islam apalagi jika mempromosikan barang dengan cara berbohong dengan melebihlebihkan kualitas barang. Melebih-lebihkan dalam Islam sangat tidak dianjurkan untuk dilakukan bagi para pedagang dengan unsur penipuan disinalah kita dituntut berlaku benar dalam melakukan suatu kegiatan. Pedagang harus melakukan perdagangan sesuai dengan aturan dalam Islam agar kita tidak melanggar etika dalam berdagang dan tidak melanggar ketentuan dari Allah.

Pedagang yang tidak kenal haram dan halal dalam berdagang menurutnya sahsah saja dalam mempromosikan barangnya ia melebih-lebihkan kualitas barang dagangannya. Bahkan ada juga sebagian pedagang menyuruh orang lain memuji barang dagangannya sehingga benyak orang lain yang tertarik dan mengaguminya pada hal barang yang dipuji belum tentu memiliki kualitas tinggi sesuai barang. Ada juga menawar dengan harga tinggi hanya untuk menipu orang lain dan ia tidak minat membeli barang tersebut dia hanya ingin menaikkan harganya dan untuk memancing pengunjung lainnya dan untuk menipu para pembeli, baik orang ini bekerja sama

${ }^{12}$ Ahmad, pentingnya menjaga kejujuran dalam Tips wirausaha.com/post/read/125/html (25 Januari 2017).

${ }^{13}$ Rudi, Wawancara, Malangke, Tanggal 17 Januari 2017 
dengan penjual atau pun tidak. Orang yang menaikkan harga, pada hal tidak minat untuk membelinya telah melanggar larangan Rasulullah dan ini merupakan dosa besar yang harus dihindari oleh setiap umat manusia

Berdagang sesuai dengan syariat Islam sangat penting untuk mendapatkan ridho dan pahala disisi Allah agar terhindar dari dosa dan mendapatkan kebahagian dunia dan akhirat.

\section{Keuntungan dalam Islam}

Hasil wawancara oleh Ibu Musliani, mengatakan bahwa dalam berdagang hanya mengambil keuntungan yang normal saja setiap harinya ia harus adil kepada konsumen dan tidak ingin mengambil keuntungan yang berlebihan dan harus berdagang sesuai dengan syariat Islam. ${ }^{14}$

Masih banyak pedagang yang mencari keuntungan sebanyak-banyak karena keuntungan adalah yang harus dicapai oleh para pedagang, dengan memanfaatkan waktu yang ada untuk mendapatkan keuntungan yang lebih tinggi tanpa memikirkan kerugian yang dialami oleh banyak orang meraka hanya memikirkan dirinya sendiri inilah suatu tindakan yang dapat merugikan konsumen.

Keadilan merupakan kesadaran dan pelaksanaan untuk memberikan kepada pihak lain sesuatu yang yang harus diterima oleh pihak lain, sehingga masing- masing pihak mendapat kesempatan yang sama untuk melaksanakan hak dan kewajibannya tanpa mengalami rintangan atau paksaan, memberi penerima yang selaras dengan hak kewajiban. Adil pada hakikatnya adalah bahwa kita memberikan kepada siapa saja apa yang menjadi haknya. Karenanya pada hakikatnya semua orang sama nilainya sebagai manusia, maka tuntutan yang paling dasariah keadilan adalah perlakuan yang sama terhadap semua orang, tentu dalam situasi yang sama. Misalnya, seseorang menjual barang daganganya dengan kualitas, jumlah, ukuran, serta waktu yang sama pada

\footnotetext{
${ }^{14}$ Musliani, Wawancara, Malangke, Tanggal 17 Januari 2017.
} 
orang lain dengan harga yang murah, maka hal tersebut harus dilakukan kepada orang lainnya. ${ }^{15}$

Hasil pengamatan yang dilakukan peneliti ada juga pedagang yang mengetahui berdagang dalam Islam tapi tidak mengaplikasikannya ia mengatakan apabila di dalam berdagang kita terlalu jujur, maka keuntungan yang didapatkan sedikit dan apabila ada sedikit kebohongan kita akan mendapatkan keuntungan yang lebih.

Hasil wawancara oleh Ibu Tuti ia mengatakan bahwa banyak pedagang yang mengambil keuntungan yang sangat tinggi dari haga pokok ia tidak mempedulikan orang lain. ${ }^{16}$

Berdagang yang tidak Islami jauh dari prinsip dan etika dalam berdagang sikap jujur, adil, dan mengutamakan kebenaran terhadap barang dagangan walau mengalami kecacatan harus dinformasikan yang sebenar-benarnya, karena dimana keuntungan yang berlebihan akan menimbulkan riba. Walaupun Islam mendorong umatnya untuk melakukan perdagangan bukan berarti berdagang sesuka hati tanpa mematuhi etika dalam berdagang yang telah ditentukan oleh Allah.

Kenyataanya dilihat sekarang ini banyak pedagang yang hanya mementingkan keuntungan dirinya sendiri tanpa memikirkan banyak orang mereka hanya mencari keuntungan yang sebanyak-banyaknya. Dimana di Pasar Belawa terjadi persaingan tidak sehat antara pedagang pada saat ramai pengunjung mereka mematok harga yang tinggi dari harga normalnya dan apabila sudah melihat kondisi pasar sudah tidak ramai pengunjung ia sudah meneurunkan harga dengan harga normalnya agar cepat laris. Ada juga dengan sengaja mengurangi takaran dalam timbangan maka disinalah terjadi konflik, konsumen kecewa kepada penjual.

Maka disinilah perlu adanya penerapan nilai-nilai syariah harus diterapkan di pasar dalam kehidupan sehari-hari karena pedagang sudah mengetahui etika yang berdagang dalam Islam.

${ }^{15}$ H. Idri, Hadis Ekonomi Dalam Perspektif Hadist Nabi (Cet: I, Jakarta; Prenadamedia Group, 2015) hal. 357-358

16 Tuti, Wawancara, Malangke, 13 Januari 2017 


\section{Menyampaikan harga pokok kepada konsumen.}

Hasil wawancara Ibu Mustidar, mengatakan bahwa pada saat berdagang tidak memberitahukan harga pokok kepada pelanggan ia hanya memberitahukan kepada pelanggan pada saat sudah terjadi tawar menawar diantara mereka dan tidak mengetahui berdagang secara Islami dan hanya mencari keuntungan saja untuk menghidupi keluaraga. ${ }^{17}$

Melihat dari pernyataan di atas bahwa pedagang tersebut tidak mengetahui berdagang secara Islam karena tidak memberitahukan kepada pelanggan harga pokok sesungguhnya dan tidak mematuhi aturan-aturan dalam berdagang Islam namun sebaiknya diawal agar pembeli merasa aman dalam membeli barang.

Menetapkan harga tidak hanyak menetapkanya sesuka hati saja namun ada halhal yang harus diperhatikan agar tidak merugikan pembeli yaitu keadilan. Dalam Islam keadilan dalam menetapkan harga sangatlah penting dalam jual beli agar harga yang ditetapkan harus sesuai dengan harga dipasaran supaya terhindar dari jual beli yang tidak sesuai dengan Islam.

Pembentukan harga di Pasar adalah hukum alam yang berlaku dimana pedagang bisa saja memanipulasi harga, menetapkan harga di Pasar untuk mendapatkan keuntungan yang sebesar-besarnya kepada konsumen tapi akan dituntutpertanggung jawabannya di hadapan Allah Swt., karena didalamnya mengandung kezaliman yang dapat merugukan banyak orang sebab dalam Islam antara permintaan dan penawaran harus terjadi pada saat rela sama rela dan tidak boleh ada paksaan sekalipun jika dalam transaski terjadi hal seperti ini maka transaksi tersebut tidak sah.

Hasil wawancara oleh bapak Ahmad nmengatakan bahwa ia tidak memberitahukan harga pokoknya kepada pembeli sekalipun pembeli menayakannya. Menurutya apabila ia memberitahukan kepada pembeli harga pokok dari barang

\footnotetext{
${ }^{17}$ Mustidar, Wawancara, Malangke, Tanggal 13 Januari 2017
} 
tersebut keuntungan yang didapatkan akan berkurang dan tidak mengetahui cara berdagang yang sesuai dengan Islam. ${ }^{18}$

Berbeda dengan ungkapan bapak Ansar ia menyatakan bahwa memang tidak memberitahukan kepada konsumen tentang harga pokok barang dagangannya namun ia tidak pernah mengambil keuntunga yang sangat tinggi, hannya mengambil keuntungan yang normal saja yang penting barang banyak yang laku, dengan banyaknya barang yang laku disitulah saya mengabil untung yang banyak tanpa merugikann orang lain. ${ }^{19}$

Banyak cara yang ditempuh oleh pedagang untuk mencari keuntungan yang lebih seperti tidak sega-segan menyebut nama Allah dalam berdagang demi untuk mencari keuntungan dengan cara yang tidak benar, dimana mengambil keuntungan yang tinggi merupakan tindakan kezaliman yang akan dipertanggung jawabkan atas perbuatannya, hal ini yang perlu diketahui oleh pedagang tapi minimya informasi yang di dapatkan oleh para pedagang membuat pedagang tidak mempraktekkan jual beli yang sesuai dengan syariat Islam. Karena berdagang dalam Islam dapat mempererat tali persaudaraan dalam hal tolong menolong, membantu sesama manusia terhadap barang yang dibutuhkannya inilah pentingnya berdagang dalam Islam karena hal-hal yang baik akan terbentuk dengan sendirinya.

\section{Adil dalam takaran dan timbangan dalam melakukan transaksi}

Hasil wawancara oleh Ibu Jusra mengatakan bahwa dulu pernah mengurangi takaran kepada barang yang dijual dia mendapatkan keutungan yang yang lebih dari barang tersebut namun, tidak berlangsung lama karena konsumen mengetahui bahwa dia mengalami kecurangan sehingga para pelanggannya tidak lagi mau membeli di tempatnya ia merasa dibohongi sehingga keuntungan yang ia dapat berkurang. ${ }^{20}$

\footnotetext{
${ }^{18}$ Ahmad, Pedagang, Wawancara, Malangke, Tanggal 11 Januari 2017.

${ }^{19}$ Ansar, Pedagang, Wawancara, Malangke, Tanggal 25 Februari.

${ }^{20}$ Jusra, Wawancara, Malangke, Tanggal 11 Januari 2017
} 
Melihat dari peristiwa di atas bahwa adil adalah suatu sifat yang harus dimiliki oleh pedagang, jika seorang tidak adil dalam melakukan transaksi akan merugikan dirinya sendiri dan hilangnya kepercayaan orang sudah percaya dengannya. Pedagang yang melakukan kecurungan mungkin beranggapan akan mendapatkan keuntungan yang lebih besar sehingga ia rela berbuat yang tidak sesuai etika dalam berdagang, dia tidak menyadari bahwa perbuatannya itu merugikan diri sendiri bukannya keuntungan yang ia dapatkan malah kerugian yang ia tanggung atas perbuatannya sendiri

Dari hasil observasi yang dilakukan masih banyak pedagang yang tidak berdagang dalam Islam, hanyak berdagang saja tanpa mengetahui etika dalam berdagang. Hal ini dipegaruhi kurangnya pengetahuan pedagang dan juga kebutuhan ekonomi yang mendorong mereka melakukan perdagangan yang tidak sesuai dengan Islam. Ada juga pedagang yang sudah mengetahui berdagang secara Islam tapi tidak mengaplikasinya disebabkan karena melihat banyak yang berlaku curang, dan tidak jujur dalam berdagang tanpa memikirkan dampak yang ditimbulkan dalam berlaku curang.

Namun saat ini sangat sulit dijumpai pedagang yang berlaku jujur mereka hanya mengejar harta sebanyak-banyaknya mendapatkan keuntungan yang berlipat ganda sehingga konsumenlah yang menjadi terzalimi, dimana di pasar tidak ada pengawasan pemerintah untuk mengontrol harga barang di pasar sehingga pedagang sesuka hati mempermainkan harga pasaran.

Penulis telah melakukan wawancara kepada ibu Marni mengatakan bahwa ia sering sekali menjumpai pendagang yang mrngurangi timbagan terhadap barang yang dibelinya, itulah sebabnya ia merasa jenuh terhadap pedagang yang seperti itu ia tidak memikirkan nasib konsumennya hanya mementingkan diri sendiri. ${ }^{21}$

Pelaku pedangang yang tidak berdagang sesuai dengan etika berdagang sesuai syariat Islam hanya memikirkan bagaimana cara mengumpulkan harta sebanyakbanyaknya keuntungan yang berlipat ganda tanpa memikirkan nasib konsumennya

\footnotetext{
${ }^{21}$ Marni, pembeli,wawancara, malangke, tanggal 25 februari 2017.
} 
tindakan seperti inilah yang sangat merugikan para konsumen yang ada di pasar untuk memenuhi kebutuhan hidupnya. Maka dari itu agar tidak lagi terjadi kecurangan, penipuan, ketidak jujuran, dan kedzaliman kepada konsumen seharusnya pedagang atau pelaku pasar harus menjujung nilai-nilai ekonomi syariah dan meningkatkan keimanan dan ketakwaan kepada Allah Swt.,

Dari hasil observasi yang dilakukan baik dari jenis pedagang dari lokasi dagang yang dtemui baru sebagian kecil pedagang yang berdagang yang sesuai dengan syariat Islam disebabkan banyaknya permasalahan dalam menerapkan nilai-nilai ekonomi syariah kurangnya pengetahuan dan informasi terhadap cara berdagang dalam Islam, inilah sebabnya pedagang kurang menerapkan atau mempraktekkan sikap jujur dalam berdagang diantaranya dari sekian banyaknya pedagang hanya sebagian kecil pedagang yang berdagang sesuai dengan syariat Islam.

Di pasar belawa ada pedagang yang belum menerapkan nilai-nilai ekonomi syariah dalam berdagang karena kurangnya pengetahuan pedagang dan tidak adanya usaha untuk mencari tau dalam Islam itu seperti apa yang pedagang pikirkan hanya menjual barang daganganya agar mendapat keuntungan, inilah menbuat hal yang buruk antara konsumen dan penjual dikarenakan tidak adanya kejelasan barang yang dijual sehingga timbullah keraguan terhadap pihak konsumen. Sebagai seorang pedagang harus mengetahui cara berdagang sesuai dengan syariat Islam yaitu penjual berusaha memberikan pelayanan yang terbaik bagi para konsumen.

Hal utama yang harus diperhatikan dalam berdagang adalah status kehalalan barang yang dijual dengan penanaman nilai iman, syariah, kejujuran, dan keadilan yang diterapkan pedagang yang ada di pasar belawa untuk melindungi pembelian barang dengan tidak sengaja yang mengandung unsur keharam yang terkandung pada barang yang dijual di pasar.

Dapat simpulkan bahwa implementasi nilai-nilai ekonomi syariah di pasar belawa belum terlaksana dengan baik, karena kurangnya pengetahuan pedagang tentang nilai-nilai syariah mereka menganggap bahwa dengan sedikit curang dalam 
berdagang akan memperoleh keuntungan yang lebih tinggi dan mereka tidak sadar apa yang dilakukannya itu merupakan dosa besar.

\section{PENUTUP}

Bentuk-bentuk ekonomi syariah di Pasar Belawa yaitu masih ada pedagang tidak bertanggung jawab atas barang dagangannya dan tidak berlaku adil terhadap konsumennya sehingga konsumen merasa dirugikan dan terzalimi oleh perlakuan pedagang dan konsumen tidak merasa nyaman dalam melakukan transaksi yang dilakukan oleh pedagang yang tidak bertanggung jawab dan pedagang yang tidak adil. Penerapan nilai-nilai ekonomi syariah di pasar Belawa belum terlaksana dengan baik disebabkan karena kurangnya pengetahuan pedagang di Pasar Belawa tentang nilainilai syariah masih ada pedagang yang berlaku curang dalam melakukan kegiatan transaksi dan tidak memperhatikan etika dalam berdagang sesuai dengan syariat Islam.

\section{DAFTAR PUSTAKA}

Departemen Agama RI, Alhikmah: Alquran Dan Terjemahan, Bandung: Diponegoro, 2010.

Departemen Agama Republik Indonesia, Alguran Dan Terjemahan, Kitab Suci Alquran Departemen Agama RI, Jakarta;Lubuk Agung Bandung, 1989

A. karim, Adiwarman, Ekonomi Mikro Islam Cet. III; Jakarta: PT. Raja Grafindo persada, 2010.

Hakim, Zikrul, Ekonomi Islam, Cet III: Jakarta: edisi revisi, 2007.

Hasan, M.Ali, Zakat Dan Infak Satu Solusi Mengatasi Problema Sosial Di Indonesia,cet.II; Jakarta: Kencana,2008.

Indri, Hadis Ekonomi Dalam Perspektif Hadis Nabi, Cet.I; Pranadamedia Group,2015

Idris, Fatah, Abdullah, Fiqih Islam Lengkap, Cet: II; PT Rineka Cipta, Jakarta, 1994

Kasmir, Pengantar Manajemen,Cet.I; Jakarta: Kencana Prenada Media, 2010. 
M. fuad, Pengantar Bisnis, Cet. I; Jakarta: Gramedia Pustaka Utama, 2000.

M. mursid, Manajemen Pemasaran, Cet. VII; Jakarta: PT. Bumi Aksara, 2014.

P3EI, Ekonomi Islami, Jakarta: Rajawali Pers, 2009.

Rasjid, Sulaiman, Fiqih Islam, Cet. 47; Bandung; Sinar Baru Algesindo Offset Bandung,2010

Raodah, Implementasi Nilai-Nilai KeIslaman Di Pasar Andi Tadda Kota Palopo, STAIN Palopo, 2014.

Ruslan, Rosadi, Metode Penelitian Public Relations dan Komonikasi, Jakarta: Raja Grafindo Persada.

Syafe'I, Rachmad,Fiqih Muamalah, Cet: I; Bandung, CV Pustaka Setia, 2011

Sukmadianita,Nana, Syaodih, Metode Penelitian Pendidikan, cet. III; bandung: PT. Remaja rosdiakarya, 2004.

Subana, Dasar-Dasar Penelitian Ilmiah, bandung: pustaka setia, 2005.

Sugiono, Metedo penelitian kualitatif dan kuantitatif C \& R Cet. VII: t.tp : CV Alfabeta, 2009.

Suriayadi, Metodologi Penelitian, Jakarta: raja grafindo persada

Yenti, Elfina, Pengaruh Pemahaman Nilai-Nilai Syariah Terhadap Perilaku Bisnis Pedagang Nianag Pada Pasar Aur Kuning Bukit Tinggi, Sumatra Barat : bukit tinggi, 2011.

Wiyaya, Oktaliana, Konsep Harga Dan Pasar Dalam Islam Http://Ukmsciemics.Blogspot.Co.Id/2011/10/Konsep- Harga-Dan-Pasar-Islam html ( 20 juni 2016)

Rahmat, konsep pasar Islam, http://anggitazure.blogspot.co.id/2012/09/konsep-pasarIslam.html (20 Juni 2014)

http://digilib.uinsby.ac.id/8051/5/bab2.pdf

Ahmad, Pentingya Kejujuran Dalam Berdagang, http;//www.tipswirausaha.com post/read/125/html (25 Januari 2017)

Http://Www.Misbah7.Com/2015/03/Pentingnya Kejujuran Bagi Kita.Html (25 Januari 2017 